\title{
Kemampuan Pemecahan Masalah Matematis Siswa Dengan Menggunakan Model Pembelajaran SSCS
}

\author{
Ika Meika ${ }^{1}$, Ina Ramadina ${ }^{2}$, Asep Sujana ${ }^{3}$, Ratu Mauladaniyati ${ }^{4}$ \\ 1,2,3,4 Program Studi Pendidikan Matematika, Universitas Mathla'ul Anwar Banten, \\ Jl. Raya Labuan KM 23, Cikaliung, Saketi, Sindanghayu, Saketi, Kabupaten Pandeglang, Banten, Indnesia \\ ikameikamulhat@gmail.com
}

\begin{abstract}
This research is a descriptive study that aims to determine students' problem solving abilites after using the SSCS learning model. The subjects of this study were 25 students of class VIII MTs Persis 72 Gunung Buntung. The learning process is carried out in accordance with the SSCS learning steps. The collection technique used tests and interviews. Based on the research result, it was foud that the percentage of students who had the ability to solve problem very well was $20 \%$, the percentage of students who had good problem's solving abilities was $72 \%$, the percentage of students with sufficient problem-solving abilities $8 \%$. Meanwhile, the highest percentage of problem's solving ability indikator is identifying the coverage of data to solve the problem of $89,33 \%$. Meanwhile, the lowest percentage of problem's solving ability indicatoris checking the correctness of the results or answers by $64,32 \%$.
\end{abstract}

Keywords: Problem Solving Abilites, Learning Model, Search Solve Create Share

\begin{abstract}
Abstrak
Masalah utama pada penelitian ini adalah rendahnya kemampuan pemecahan masalah matematis siswa MTs Persis 72 Gunung Buntung. Adaun penelitian ini merupakan penelitian deskriptif bertujuan untuk mengetahui kemampuan pemecahan masalah siswa setelah menggunakan model pembelajaran SSCS. Subjek penelitian ini adalah siswa kelas VIII MTs Persis 72 Gunung Buntung berjumlah 25 orang. Proses pembelajaran yang dilaksanakan sesuai dengan langkah pembelajaran SSCS. Teknik pengumpulan yang digunakan tes dan wawancara. Berdasarkan hasil penelitian, diperoleh persentase siswa yang memiliki kemampuan pemecahkan masalah dengan sangat baik sebesar $20 \%$, persentase siswa yang memiliki kemampuan pemecahan masalah dengan baik sebesar $72 \%$, persentase siswa dengan kemampuan pemecahan masalah cukup sebesar $8 \%$. Sedangkan persentase indikator kemampuan pemecahan masalah paling tinggi adalah mengidentifikasi kecakupan data untuk memecahkan masalah sebesar 89,33\%. Sedangkan Persentase indikator kemampuan pemecahan masalah paling rendah adalah Memeriksa kebenaran hasil atau jawaban sebesar 64,32\%.
\end{abstract}

Kata kunci: Kemampuan Pemecahan Masalah, Model Pembelajaran, Search Solve Create Share

Copyright (c) 2021 Ika Meika, Ina Ramadina, Asep Sujana, Ratu Mauladaniyati

$\triangle$ Corresponding author: Ika Meika

Email Address: ikameikamulhat@gmail.com (Jl. Raya Labuan KM 23, Cikaliung, Pandeglang, Banten, Indonesia)

Received 26 November 2020, Accepted 08 Maret 2021, Published 09 Maret 2021

\section{PENDAHULUAN}

Matematika merupakan salah satu mata pelajaran yang memiliki peran penting bagi ilmu pengetahuan lainnya. Namun sampai saat ini, masih banyak siswa yang beranggapan bahwa matematika merupakan mata pelajaran yang paling sulit bahkan menakutan. Hal tersebut dapat menghambat proses pembelajaran matematika secara efektif. Pola Bilangan merupakan salah satu materi yang penting dalam pembelajaran matematika. Materi mengenai pola bilangan sangat bermanfaat untuk memecahkan masalah yang kita temui dalam kehidupan nyata.

Menurut Wardhani (2008:2) pembelajaran matematika di sekolah memiliki tujuan agar siswa mampu: (1) memahami konsep matematika, menjelaskan keterkaitan antarkonsep dan mengaplikasikan konsep atau algoritma, secara luwes, akurat, efisien, dan tepat dalam pemecahan 
masalah, (2) menggunakan penalaran pada pola dan sifat, melakukan manipulasi matematika dalam membuat generalisasi, menyusun bukti, atau menjelaskan gagasan dan pernyataan matematika, (3) memecahkan masalah yang meliputi kemampuan memahami masalah, merancang model matematika, menyelesaikan model, dan menafsirkan solusi yang diperoleh, (4) mengomunikasikan gagasan dengan simbol, tabel, diagram, atau media lain untuk memperjelas keadaan atau masalah, (5) memiliki sikap menghargai kegunaan matematika dalam kehidupan, yaitu memiliki rasa ingin tahu, perhatian, dan minat dalam mempelajari matematika, serta sikap ulet dan percaya diri dalam pemecahan masalah.

Pada abad 21 sekarang ini, tujuan pembelajaran matematika adalah siswa diharapkan memiliki karakteristik 4C, yaitu: Communication, Collaboration, Critical Thinking and Problem Solving, Creativity and Innovation. Hal ini juga sejalan dengan National Council of Teachers of Mathematics (NCTM,2017) yang menetapkan lima standar kemampuan matematis untuk dapat mewujudkan tujuan dalam pembelajaran Matematika yaitu kemampuan pemecahan masalah (problem solving), kemampuan penalaran (Reasoning and Proof), kemampuan komunikasi (communication), kemampuan koneksi (connection) dan kemampuan representasi (representation). Pembelajaran matematika disekolah tidak hanya bertujuan untuk memahami materi yang diajarkan saja, tetapi tujuan utamanya yaitu agar siswa memiliki kemampuan penalaran, komunikasi, representasi dan pemecahan masalah (Ariawan \& Nufus, 2017).

Prestasi matematika siswa Indonesia dalam kejuaraan internasional semakin meningkat. Hal ini ditunjukan dengan berhasilnya siswa Indonesia membawa pulang satu medali emas dan 6 medali perunggu dari ajang Internasional Mathematic Olympiad (IMO) ke-59 di Cluj-Napoca, Rumania. Olimpiade yang berlangsung pada tanggal 4-14 Juli 2018 diikuti oleh 106 negara dari 600 peserta. Perolehan tersebut menaikkan posisi Indonesia ke posisi 10 besar setelah pada tahun sebelumnya berada pada peringkat ke-43 dari 104 negara. Prestasi tersebut menjadi kebanggaan bagi Indonesia. Namun, prestasi tersebut adalah prestasi individual, dan tidak mencerminkan prestasi siswa Indonesia secara menyeluruh. Pada kenyataannya, prestasi matematika siswa Indonesia masih rendah. Hal ini ditunjukan pada hasil survei yang dilakukan oleh Programme for International Student Assessment (PISA) dibawah Cooperation and Development (OECD) yang dilakukan pada 65 negara di dunia pada tahun 2018 lalu, yang menyatakan bahwa kemampuan matematika siswa-siswi di Indonesia menduduki peringkat bawah dengan skor 379. Nilai ini mengalami penurunan dibandingkan dengan tes tahun 2015 dengan skor 386. Hal tersebut sangatlah memprihatinkan dunia pendidikan.

Rendahnya prestasi belajar pada pelajaran matematika dipengaruhi oleh banyak faktor, salah satunya adalah kurangnya kemampuan pemecahan masalah matematis siwa. Selain itu, berdasarkan observasi di lapangan, mata pelajaran matematika masih kurang diminati oleh siswa, karena masih ada dugaan bahwa matematika adalah mata pelajaran yang sukar serta pembelajarannya yang kurang menyenangkan untuk siswa sehingga siswa enggan untuk mempelajari matematika lebih dalam, oleh sebab itu pembelajaran yang menarik harus dilakukan agar mendapat respon positif terhadap matematika. 
Berdasarkan hasil observasi yang dilakukan di MTs Persis 72 Gunung Buntung Kabupaten Serang rendahnya kemampuan pemecahan masalah terlihat dari data nilai hasil belajar siswa yang diperoleh yaitu dengan nilai rata-rata nilai siswa hanya mencapai 58,0. Angka ini jauh dibawah Kriteria Ketuntasan Minimum (KKM) yang ditentukan sekolah yaitu 70,0. Selain berdasarkan hasil ulangan harian, wawancara dengan guru mata pelajaran matematika di sekolah tersebut, dan dari hasil wawancara dengan siswa, peneliti juga memberikan soal-soal yang memuat indikator kemampuan pemecahan masalah matematis menurut mudrikah dengan persentase per indikator yaitu 43,93\% untuk indikator pertama, 34,1\% untuk indikator kedua, 31,8\% untuk indikator ketiga, 27,28\% untuk indikator keempat dan 35,23\% untuk indikator kelima. Berdasarkan hasil observasi dan prapenelitian sehingga dapat ditarik kesimpulan bahwa sebagian siswa-siswa di sekolah tersebut sangat lemah dalam hal pemecahan masalah matematis, mereka sangat kesulitan dalam mengerjakan soal-soal cerita maupun soal-soal aplikasi.

Pemecahan masalah matematis sangat berperan penting dalam proses pembelajaran karena siswa kemungkinan akan memperoleh soal atau masalah yang tidak rutin. Kemampuan pemecahan masalah matematis penting dikuasai siswa. Selain itu, kemampuan pemecahan masalah matematis siswa yang belum optimal. Oleh karena itu kita perlu mencari alternatif metode pembelajaran yang mampu meningkatkan kemampuan pemecahan masalah matematis siswa. Untuk mengantisipasi masalah tersebut maka perlu dicarikan suatu formula model, metode atau pendekatan pembelajaran yang tepat sehingga dapat meningkatkan kemampuan pemecahan masalah matematis dalam menyelesaikan soal matematis. Para guru hendaknya terus berusaha menyusun dan menerapkan berbagai variasi agar siswa tertarik dan bersemangat dalam mengikuti pelajaran matematika.

Menurut Yuli Mulyana (2018), upaya yang diduga dapat meningkatan kemampuan membuat model matematis dan kerja sama siswa yaitu dengan model pembelajaran Search Solve Create and Share (SSCS). Namun menurut Yusnaeni dan Corebima (2017: 3477), pembelajaran dengan model SSCS merupakan salah satu model pembelajaran kooperatif yang sangat tepat untuk meningkatkan kemampuan pemecahan masalah matematis siswa. Model pembelajaran Search Solve Create Share (SSCS) pertama kali diperkenalkan pada tahun 1987 oleh Edward L. Pizzini, yang meliputi empat fase, yaitu fase Search yang bertujuan untuk mengidentifikasi masalah yang mengenai pokok bahasan Pola Bilangan. Fase kedua, fase Solve yang bertujuan untuk merencanakan penyelesaian masalah yang mengenai pokok bahasan Pola Bilangan. Fase ketiga, fase Create yang bertujuan untuk melaksanakan penyelesaian masalah yang mengenai pokok bahasan Pola Bilangan. Fase keempat adalah fase Share yang bertujuan untuk mensosialisasikan penyelesaian masalah yang mengenai pokok bahasan Pola Bilangan (Hunaeni, 2013: 5).

Menurut Eka Periartawan (2014) Model pembelajaran Search Solve Create Share (SSCS) merupakan salah satu model pembelajaran yang dapat meningkatkan kemampuan pemecahan masalah matematis dan model pembelajaran yang dapat diaplikasikan secara nyata dalam pembelajaran menggunakan kurikulum 2013. Aktivitas siswa dapat berjalan dengan baik karena melibatkan siswa 
secara langsung dalam pembelajaran. Karena didalam model tersebut terdapat langkah-langkah yang mendukung untuk meningkatkan kemampuan pemecahan masalah matematis yaitu pada tahap Solve serta model tersebut pernah diuji cobakan oleh Eka periartawan di sekolah dasar, peneliti akan menjadikan model pembelajaran Search Solve Create Share (SSCS) sebagai solusi untuk meningkatkan kemampuan pemecahan masalah matematis.

Berdasarkan uraian di atas, peneliti tertarik untuk mengkaji Model Pembelajaran SSCS dan kemampuan pemecahan masalah, sehingga tujuan penelitian ini adalah untuk melihat kemampuan pemecahan masalah siswa setelah menggunakan model pembelajaran SSCS.

\section{METODE}

Jenis penelitian ini adalah penelitian deskriptif yang bertujuan untuk mendeskripsikan kemampuan pemecahan masalah siswa setelah menggunakan model pembelajaran SSCS. Variabel dalam penelitian ini adalah kemampuan pemecahan masalah siswa setelah melakukan pembelajaran menggunakan Model SSCS. Kemampuan pemecahan masalah adalah suatu usaha siswa untuk menemukan jalan keluar atau solusi dari permasalahan sehingga mendapatkan hasil akhir atau jawaban dari permasalahan tersebut. Menurut Mudrikah (Amam, A. 2017) Indikator pemecahan masalah matematika adalah Mengidentifikasi kecakupan data untuk memecahkan masalah, Membuat model matematik dari suatu situasi atau masalah sehari-hari dan menyelesaikannya, Memilih dan menerapkan strategi untuk menyelesaikan berbagai masalah dalam atau luar matematika, Menjelaskan atau menginterpretasikan hasil sesuai permasalahan asal, serta memeriksa kebenaran hasil atau jawaban dan Menerapkan matematika secara bermakna.

Subjek penelitian ini adalah siswa kelas VIII B MTs Persis 72 Gunung Buntung yang berjumlah 25 orang. Dalam penelitian ini, teknik pengumpulan data melalui tes soal kemampuan pemecahan masalah matematis yang diberikan kepada siswa. Tes yang diberikan berupa tes tertulis bentuk uraian yang terdiri dari 5 soal pemecahan masalah terkait materi pola bilangan yang dikerjakan siswa secara individu. Untuk memperjelas metode penelitian yang digunakan, berikut bagan alir dari penelitian ini dapat dilihat di bagan 1 .

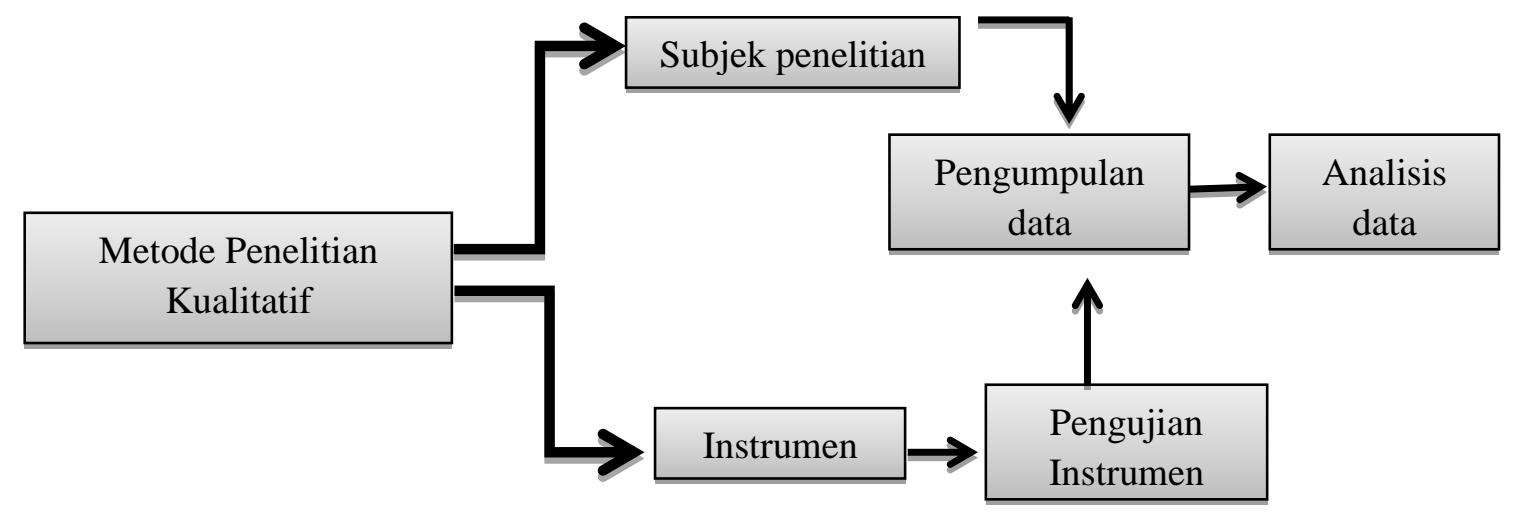

Bagan 1. Bagan Alir Penelitian 
Kemampuan Pemecahan Masalah Matematis Siswa Dengan Menggunakan Model Pembelajaran SSCS, Ika Meika, Ina Ramadina, Asep Sujana ${ }^{3}$, Ratu Mauladaniyati

Setelah tes dilakukan, akan didapatkan skor untuk setiap siswa. Skor tersebut dijumlahkan kemudian dianalisis. Langkah yang dilakukan adalah menentukan nilai tes siswa dengan memberi skor pada jawaban siswa sesuai dengan rubrik penskoran yang telah dibuat. Selanjutnya menjumlahkan skor keseluruhan yang diperoleh oleh siswa dengan skor maksimum 90 skor dalam bentuk nilai rentang (0-100). Langkah untuk menganalisis data hasil tes tertulis adalah menentukan nilai tes siswa dan menentukan kategori kemampuan pemecahan masalah siswa dapat dilihat pada tabel 1.

Tabel 1. Kategori Kemampuan Pemecahan Masalah Matematis

\begin{tabular}{|c|c|}
\hline Nilai Siswa & Kategori Penilaian \\
\hline $81-100$ & Sangat Baik \\
\hline $61-80$ & Baik \\
\hline $41-60$ & Cukup \\
\hline $21-40$ & Kurang \\
\hline $0-20$ & Sangat Kurang \\
\hline
\end{tabular}

(Arikunto Suharsimi: 2006)

Adapun tahapan yang terakhir adalah menentukan persentase kemunculan indikator kemampuan pemecahan masalah siswa.

\section{HASIL}

Penelitian dilaksanakan sebanyak 4 pertemuan dengan tiga pertemuan untuk kegiatan pembelajaran dan satu pertemuan terakhir untuk tes kemampuan pemecahan masalah. Pembelajaran dilaksanakan sesuai langkah-langkah model pembelajaran SSCS. Data mengenai kemampuan pemecahan masalah siswa diperoleh dari hasil tes dengan menggunakan tipe soal pemecahan masalah. Tes dilaksanakan pada pertemuan keempat atau pertemuan terakhir. Tes dikerjakan oleh siswa secara individu. Penskoran yang dilakukan adalah sesuai dengan rubrik penskoran yang telah dibuat.

Setelah semua jawaban siswa diperiksa dan diberikan skor sesuai rubrik penskoran, maka langkah selanjutnya adalah menjumlahkan skor yang diperoleh dari ketiga soal tersebut lalu dibagi dengan skor maksimal yaitu 100, kemudian dikalikan 100. Setelah diperoleh nilai siswa, selanjutnya nilai tersebut dikelompokkan ke dalam lima kategori kemampuan pemecahan masalah yang dapat dilihat pada tabel 3 berikut.

Tabel 2. Nilai Kemampuan Pemecahan Masalah Matematis

\begin{tabular}{|c|c|c|c|}
\hline Nilai Siswa & Frekuensi & Persentasi & Kategori Penilaian \\
\hline $81-100$ & 5 & $20 \%$ & Sangat Baik \\
\hline $61-80$ & 18 & $72 \%$ & Baik \\
\hline $41-60$ & 2 & $8 \%$ & Cukup \\
\hline $21-40$ & 0 & $0 \%$ & Kurang \\
\hline $0-20$ & 0 & $0 \%$ & Sangat Kurang \\
\hline Jumlah & 25 & $100 \%$ & \\
\hline Rata-rata & \multicolumn{2}{|c|}{74,66} & \\
\hline
\end{tabular}


Kemudian, untuk melihat persentase kemunculan indikator kemampuan pemecahan masalah dari jawaban siswa terhadap soal tes dapat dilihat pada tabel 4 di bawah ini.

Tabel 3. Persentasi Indikator Kemampuan Pemecahan Masalah Matematis

\begin{tabular}{|l|c|}
\hline \multicolumn{1}{|c|}{ Indikator } & Persentasi \\
\hline Mengidentifikasi kecakupan data untuk memecahkan masalah & $89,33 \%$ \\
\hline $\begin{array}{l}\text { Membuat model matematik dari suatu situasi atau masalah sehari-hari } \\
\text { dan menyelesaikannya }\end{array}$ & $66,4 \%$ \\
\hline $\begin{array}{l}\text { Memilih dan menerapkan strategi untuk menyelesaikan berbagai } \\
\text { masalah dalam atau luar matematika }\end{array}$ & $72,6 \%$ \\
\hline Memeriksa kebenaran hasil atau jawaban & $64,32 \%$ \\
\hline Menerapkan matematika secara bermakna. & $84,6 \%$ \\
\hline
\end{tabular}

Penelitian tentang kemampuan pemecahan masalah siswa kelas VIII B bertujuan untuk mengetahui kemampuan pemecahan masalah siswa kelas VIII B di MTs Persis 72 Gunung Buntung yang ditunjukkan melalui soal tes yang diberikan. Pembelajaran dilaksanakan sesuai langkah-langkah pembelajaran dengan model pembelajaran SSCS. Selama proses pembelajaran berlangsung, guru menggunakan lembar kerja siswa (LKS) untuk mengefektifkan proses pembelajaran. LKS yang digunakan telah didesain dan disesuaikan dengan pembelajaran dengan model pembelajaran SSCS.

Berdasarkan analisis hasil tes siswa, terlihat bahwa persentase kemunculan rata-rata kemampuan pemecahan masalah siswa tertinggi terletak pada indikator mengidentifikasi kecakupan data untuk memecahkan masalah yaitu sebesar $89,33 \%$. Sedangkan yang terendah terletak pada indikator memeriksa kebenaran hasil atau jawaban yaitu $64,32 \%$.

\section{KESIMPULAN}

Berdasarkan hasil penelitian di kelas VIII B MTs Persis 72 Gunung Buntung, diperoleh gambaran kemampuan pemecahan masalah siswa dengan menggunakan model pembelajaran SSCS pada materi pola bilangan dapat dikategorikan baik dengan rincian sebagai berikut : persentase siswa yang memiliki kemampuan pemecahkan masalah dengan sangat baik sebesar 20\%, persentase siswa yang memiliki kemampuan pemecahan masalah dengan baik sebesar $72 \%$, persentase siswa dengan kemampuan pemecahan masalah cukup sebesar $8 \%$. Sedangkan persentase indikator kemampuan pemecahan masalah paling tinggi adalah mengidentifikasi kecakupan data untuk memecahkan masalah sebesar 89,33 \%. Sedangkan Persentase indikator kemampuan pemecahan masalah paling rendah adalah Memeriksa kebenaran hasil atau jawaban sebesar 64,32\%.

\section{UCAPAN TERIMA KASIH}

Penelitian ini dapat dilaksanakan dengan baik berkat bantuan dari berbagai pihak. Untuk itu, peneliti ingin mengucapkan terima kasih kepada FKIP Universitas Mathla'ul Anwar Banten serta MTs Persis 72 Gunung Buntung yang telah memberikan kerjasama yang baik dalam penelitian ini. Selain itu, 
Kemampuan Pemecahan Masalah Matematis Siswa Dengan Menggunakan Model Pembelajaran SSCS, Ika Meika, Ina

ucapan terima kasih dan penghargaaan diberikan kepada editor yang telah menelaah dan mereview Jurnal Cendikia ini.

\section{DAFTAR PUSTAKA}

Afifah, S. N., Hartono, Y., \& Yusuf, M. (2016). Kemampuan Pemecahan Masalah Matematika Siswa Kelas VII. 1 Dalam Pembelajaran Berbasis Proyek Materi Aritmatika Sosial Di SMP Negeri 1 Palembang (Doctoral dissertation, Sriwijaya University).

Amam, A. (2017). Penilaian kemampuan pemecahan masalah matematis siswa SMP. Teorema: Teori dan Riset Matematika, 2(1), 39-46.

Arikunto, S. (2019). Prosedur penelitian suatu pendekatan praktik.

Armada, I. N., Tegeh, I. M., \& Sudiana, I. W. (2013). Pengaruh Model Pembelajaran Means-Ends Analysis (MEA) Terhadap Hasil Belajar Matematika Pada Siswa Kelas V SD Gugus V Kecamatan Sukasada. MIMBAR PGSD Undiksha, 1(1).

Apriyanti, R., Umbara, U., \& Puadi, E. F. W. (2017). PEnerapan Model Pembelajaran Sscs (Search, Solve, Create And Share) Terhadap Peningkatan Kemampuan Pemecahan Masalah Matematis Siswa SMP. JUMLAHKU: Jurnal Matematika Ilmiah STKIP Muhammadiyah Kuningan, $3(2), 1-8$.

Ariawan, R., \& Nufus, H. (2017). Hubungan kemampuan pemecahan masalah matematis dengan kemampuan komunikasi matematis siswa. Jurnal THEOREMS (The Original Research of Mathematics), 1(2), 82-91.

Anggraini, L., Siroj, R. A., \& Indra, I. (2009). PENERAPAN MODEL PEMBELAJARAN INVESTIGASI PEMECAHAN MASALAH MATEMATIKA SISWA KELAS VIII-4 SMP NEGERI 27 PALEMBANG.

Ganesha, U. P. (n.d.). PENGARUH MODEL PEMBELAJARAN MEANS-ENDS ANALYSIS ( MEA ) TERHADAP HASIL BELAJAR MATEMATIKA PADA SISWA KELAS V SD GUGUS V KECAMATAN SUKASADA.

Hunaeni, Y. (2013). Upaya Meningkatkan Kemampuan Penalaran Matematis Siswa Smp Melalui Model Pembelajaran Search, Solve, Create And Share (SSCS): Penelitian Kuasi Eksperimen terhadap Siswa Kelas VII SMP Negeri 15 Bandung (Doctoral dissertation, Universitas Pendidikan Indonesia).

Inayah, S. (2018). Penerapan Pembelajaran Kuantum Untuk Meningkatkan Kemampuan Pemecahan Masalah Dan Representasi Multipel Matematis Siswa. KALAMATIKA Jurnal Pendidikan Matematika, 3(1), 1-16.

Mulyana, Y., Priyatno, S., \& Dewi, N. R. (2018). Penerapan Model SSCS untuk Meningkatkan Kemampuan Membuat Model Matematis dan Kerja Sama Siswa. 1, 340-341.

Murniati, S., Winarti, E. R., \& Irawanti, I. (2019, February). Meningkatkan Kemampuan Pemecahan Masalah dan Kerjasama Siswa SMPN 24 Semarang melalui Model Pembelajaran SSCS. In PRISMA, Prosiding Seminar Nasional Matematika (Vol. 2, pp. 99-102).

Noor, A. J. (2014). KEMAMPUAN PEMECAHAN MASALAH MATEMATIKA SISWA DALAM. 2, 250-259. 
Noor, A. J., \& Norlaila, N. (2014). Kemampuan Pemecahan masalah matematika siswa dalam pembelajaran matematika menggunakan model cooperative script. EDU-MAT: Jurnal Pendidikan Matematika, 2(2).

NCTM. (2017). Principles and Standards for School Mathematics. Reston. VA: NCTM.

Prihatiningtyas, N. C., \& Nurhayati, N. (2017). Penerapan Model Pembelajaran Means-Ends Analysis Untuk Meningkatkan Kemampuan Pemecahan Masalah Matematis Siswa. JPMI (Jurnal Pendidikan Matematika Indonesia), 2(1), 13-18.

Periartawan. E. dkk (2014). Pengaruh Model Pembelajaran SSCS Terhadap Kemampuan Pemecahan Masalah Matematika Siswa Kelas IV digugus XV Kalibukbuk. Jurnal Mimbar PGSD Universitas Pendidikan Ganesha. 2, 1.

Rafianti, I., Iskandar, K., \& Haniyah, L. (2020). Pembelajaran Search, Solve, Create and Share (SSCS) untuk Meningkatkan Pemahaman Konsep dan Disposisi Matematis Siswa. Journal of Medives: Journal of Mathematics Education IKIP Veteran Semarang, 4(1), 97-110.

Wardhani, S. (2008). Analisis SI dan SKL mata pelajaran matematika SMP/MTs untuk optimalisasi tujuan mata pelajaran matematika. Yogyakarta: PPPPTK.

Yusnaeni, A., \& Corebima, D. (2017). Empowering students 'metacognitive skills on sscs learning model integrated with metacognitive strategy. The International Journal of Social Sciences and Humanities Invention, 4, 3476-3481. 